\title{
Tapered Stent Length
}

National Cancer Institute

\section{Source}

National Cancer Institute. Tapered Stent Length. NCI Thesaurus. Code C150196.

The leng th of the tapered portion of the stent. 